\title{
MANAJEMEN KESAN DISPARBUDPORA SUMENEP DALAM MEMBANGUN CITRA DESTINASI WISATA
}

\author{
THE SUMENEP TOURISM, CULTURE, YOUTH AND SPORTS OFFICE \\ IMPRESSION MANAGEMENT IN DEVELOPING TOURISM DESTINATION \\ IMAGE
}

\author{
Mohammad Insan Romadhan \\ Ilmu Komunikasi FISIP, Universitas 17 Agustus 1945 Surabaya \\ Semolowaru 45 Surabaya \\ insanromadhan@untag-sby.ac.id
}

Diterima: 04 Februari 2020

Direvisi: 16 Juli 2020

Disetujui: 10 Mei 2021

\begin{abstract}
In the tourism industry, geographical location is a key factor in managing tourist destinations. Sumenep is geographically located in the eastern tip of Madura Island and does not offer multiple modes of public transportation like other big cities. However, both facts do not hamper tourists to visit this city considering the growing number of tourists every year. Therefore, it is noteworthy to examine the impression management of the Sumenep Department of Tourism, Culture, Youth and Sports in developing tourism destination image. The research used descriptive qualitative design. Data was collected using in-depth interviews and observation, whereas the validity was verified using source triangulation method. The results showed that the impression management to develop a tourist destination image has been carried out by the Sumenep Tourism, Culture, Youth and Sports Office using three strategies, i.e. ingratiation, self-promotion and exemplification. The other strategies, supplication and intimidation, were not applied. It can be seen from various kinds of activities designed to promote tourist destinations in Sumenep, especially in the Visit Sumenep Program, which mostly consists of performances and festivals, as well as the promotion of local nature and cultural tourism.
\end{abstract}

Keywords: Impression Management, Sumenep Tourism, Cultural, Youth and Sports Office, Tourism Destination Image

\begin{abstract}
ABSTRAK
Dalam industri pariwisata, letak geografis sebuah daerah menjadi hal yang penting dalam mengelola destinasi wisatanya. Sumenep, secara geografis terletak di ujung timur Pulau Madura dan belum memiliki banyak pilihan moda transportasi seperti kota besar lainnya. Akan tetapi, faktanya hal tersebut tidak menjadi masalah, mengingat jumlah wisatawan yang meningkat setiap tahunnya. Melihat fenomena tersebut, peneliti tertarik untuk mengkaji bagaimana manajemen kesan Dinas Pariwisata, Kebudayaan, Pemuda dan Olahraga Sumenep dalam membangun citra destinasi wisata di kota tersebut. Penelitian ini menggunakan desain deskriptif kualitatif. Teknik pengumpulan data yang digunakan adalah wawancara mendalam dan observasi. Adapun uji keabsahan data dilakukan menggunakan triangulasi sumber. Hasil penelitian menunjukkan bahwa manajemen kesan untuk membangun citra destinasi wisata di Sumenep, dilakukan Dinas Pariwisata, Kebudayaan, Pemuda dan Olahraga dengan menggunakan strategi ingratiation, self-promotion dan exemplification. Adapun strategi supplication dan intimidation tidak dilakukan. Hal tersebut tampak dari berbagai kegiatan untuk mengenalkan destinasi wisata yang ada di Sumenep, khususnya dalam Program Visit Sumenep, yang banyak berisi pagelaran, festival dan promosi destinasi wisata alam maupun budaya.
\end{abstract}

Kata Kunci: Manajemen Kesan, Disparbudpora Sumenep, Citra Destinasi Wisata 


\section{PENDAHULUAN}

Untuk mengenalkan sekaligus mempromosikan pariwisata yang ada di daerahnya, Dinas Pariwisata, Kebudayaan, Pemuda dan Olahraga Sumenep meluncurkan Program Visit Sumenep. Program ini meliputi berbagai kegiatan mulai dari festival, perlombaan hingga acara peringatan yang menjadi ciri khas dan karakteristik Sumenep, yang digelar untuk mendorong wisatawan agar berkunjung. Program Visit Sumenep yang diselenggarakan pada tahun 2018, dibuka dengan acara Sumenep Mengukir dan acara puncak berupa festival keraton dan masyarakat adat se-ASEAN pada bulan Oktober 2018. Keberhasilan Program Visit Sumenep 2018 membuat Dinas Pariwisata Kebudayaan Pemuda dan Olahraga Sumenep kembali mengadakan Program Visit Sumenep pada tahun 2019.

Konsep dari Program Visit Sumenep 2019 secara garis besar masih sama dengan Program 2018. Berikut kutipan berita Program Visit Sumenep 2018:

Visit Sumenep 2018 mempersiapkan 36 event unggulan yang akan digelar selama setahun penuh. Di antaranya berupa festival budaya, religi, sejarah, olahraga, serta festival kesehatan yang menjadi tema dan salah satu ikon pariwisata Sumenep (Arivin, 2018).

Kutipan berita di atas menunjukkan bahwa pada tahun 2018 ada 36 kegiatan yang diadakan dalam Program Visit Sumenep 2018. Kegiatan itu meliputi pagelaran budaya, festival maupun perlombaan. Berikut adalah agenda dari Program Visit Sumenep 2018:

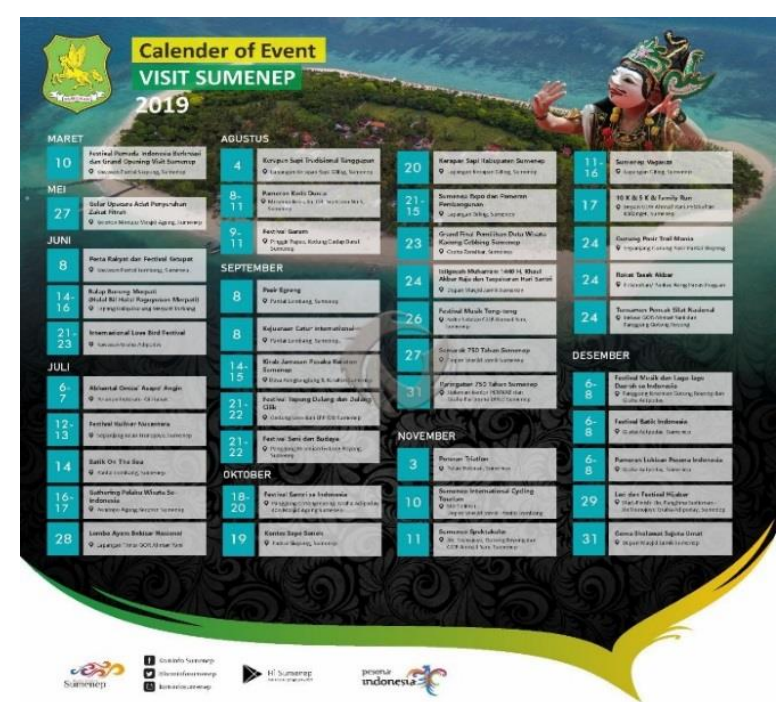

Gambar 1. Kalender Visit Sumenep 2018

Sumber: archipelago-indonesia. 2018.

Selain itu, pelaksanaan kegiatan dalam Program Visit Sumenep tahun 2019 tidak jauh berbeda dengan program di tahun sebelumnya. Ada beberapa kegiatan yang tetap dipertahankan, ada yang dihilangkan dan ada beberapa kegiatan yang ditambahkan. Berikut agenda Program Visit Sumenep 2019:

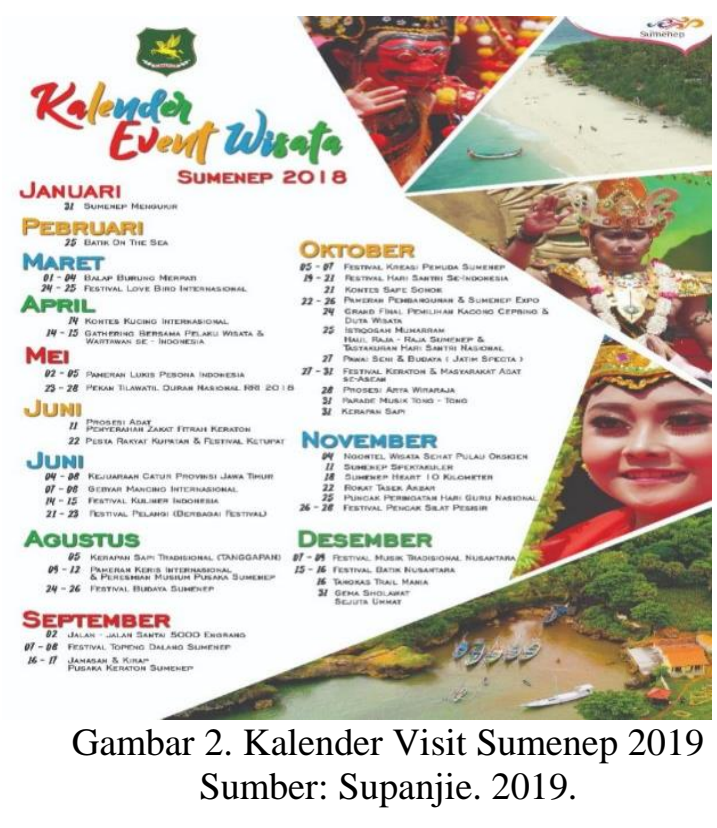




\section{Penyelenggaraan Program Visit}

Sumenep ini merupakan bukti keseriusan Pemerintah Daerah Sumenep, khususnya Dinas Pariwisata, Kebudayaan, Pemuda dan Olahraga dalam membangun pariwisata di daerahnya.

Tercatat dari tahun 2015 hingga 2018 terjadi peningkatan jumlah wisatawan yang berkunjung ke Sumenep hampir dua kali lipat. Bahkan, wisatawan mancanegara meningkat jumlahnya hingga enam kali lipat. Berikut tabelnya:

Tabel 1. Jumlah Wisatawan di Sumenep Madura

\begin{tabular}{cccc}
\hline Tahun & $\begin{array}{c}\text { Wisatawan } \\
\text { Mancanegara }\end{array}$ & $\begin{array}{c}\text { Wisatawan } \\
\text { Domestik }\end{array}$ & Total \\
\hline 2015 & 417 & 626.926 & 627.343 \\
\hline 2016 & 1.332 & 854.614 & 855.946 \\
\hline 2017 & 4.036 & 1.047 .109 & 1.051 .145 \\
\hline 2018 & 2.694 & 1.285 .325 & 1.288 .019 \\
\hline
\end{tabular}

Sumber: Disparbudpora Sumenep. 2019.

Selain itu, dalam beberapa tahun terakhir, pariwisata menjadi semakin diminati oleh banyak elemen masyarakat, mulai dari anak muda, pekerja hingga keluarga. Hal tersebut terjadi bersamaan dengan upaya setiap daerah dalam mengenalkan potensi wisatanya masing-masing. Hal ini membuat sektor pariwisata menjadi menggeliat.

Daerah-daerah yang menjadi destinasi wisata favorit di tanah air telah memiliki citra wisata yang well-established di benak wisatawan. Bali misalnya, terkenal dengan citra destinasi wisata alam dan budayanya yang mempesona. Lombok, dengan Gili Trawangan sebagai maskotnya, mencitrakan pariwisata daerahnya sebagai pulau yang bebas dari kendaraan bermotor. Daerah-daerah tersebut merupakan contoh akan pentingnya membangun citra destinasi wisata demi kelangsungan eksistensi pariwisata di daerah tersebut. Artinya, dapat dikatakan bahwa keberhasilan dalam menarik wisatawan juga ditentukan oleh citra publik tentang suatu objek wisata.

Berdasarkan observasi yang peneliti lakukan, Sumenep menyimpan banyak potensi pariwisata dan kekayaan budaya, mulai dari wisata alam, seperti pantai dan kepulauan Gili. Sumenep juga mempunyai objek wisata religi, seperti pemakaman raja Sumenep, objek wisata sejarah seperti museum dan keraton Sumenep, objek wisata budaya seperti Kerapan Sapi, dan lain sebagainya. Jadi, tidak salah bila Sumenep dijadikan referensi destinasi wisata yang patut dikunjungi wisatawan.

Akan tetapi, potensi tersebut akan menjadi percuma jika tidak dikelola dengan baik. Ini berarti, Dinas Pariwisata, Kebudayaan, Pemuda dan Olahraga Sumenep memiliki tugas untuk mengenalkan berbagai potensi tersebut kepada masyarakat luas, sehingga dapat menarik minat wisatawan untuk berkunjung ke Sumenep. Untuk itu, citra destinasi wisata Sumenep perlu dibangun agar mudah dikenali oleh wisatawan.

Ketika peneliti menggali data di Dinas Pariwisata, Kebudayaan, Pemuda dan Olahraga Sumenep, ada hal menarik yang disampaikan oleh Kepala Seksi Promosi. Berikut kutipan wawancaranya:

"Secara lokasi, Sumenep ini agak berbeda dengan tempat-tempat wisata lainnya. Yang membedakan, secara geografis Sumenep merupakan daerah ujung sehingga hanya orang yang berniat berkunjung saja yang akan mengunjungi Sumenep. Berbeda dengan Banyuwangi yang merupakan daerah 
transit. Jadi, sebelum ke Bali, wisatawan bisa sekalian mampir ke Banyuwangi, karena merupakan daerah transit. Ini menyebabkan Banyuwangi lebih mudah menarik wisatawan. Sama seperti Bandung, sebelum orang pergi ke Jakarta, mereka bisa mampir dulu ke Bandung”. (Ronny Arif Y, Wawancara, Kepala Seksi Promosi Dinas Pariwisata, Kebudayaan, Pemuda dan Olahraga Sumenep).

Dari wawancara dengan informan tersebut diketahui bahwa secara geografis, lokasi Sumenep yang terletak di ujung timur Pulau Madura berdampak pada jumlah kunjungan wisatawan. Ini disebabkan wisatawan yang akan berkunjung ke Sumenep hanya dapat berkunjung di Sumenep saja mengingat lokasinya merupakan lokasi tujuan, bukan daerah transit. Hal itu menjadi tantangan tersendiri bagi Dinas Pariwisata, Kebudayaan, Pemuda dan Olahraga Sumenep untuk dapat membangun citra destinasi wisata daerahnya dengan mempertimbangkan lokasinya yang kurang menguntungkan.

Berkaca pada penelitian sebelumnya yang juga peneliti lakukan di Sumenep mengenai proses komunikasi dalam pelestarian budaya Saronen kepada generasi muda Sumenep, peneliti menemukan bahwa komunikasi yang dilakukan lebih banyak menggunakan komunikasi tatap muka, baik itu dari Disparbudpora kepada pelaku budaya maupun pelaku budaya kepada generasi muda. Dari penelitian tersebut, peneliti melihat keseriusan Disparbudpora Sumenep dalam melestarikan budaya setempat.

Pada penelitian lainnya, peneliti berupaya untuk mengkaji peran festival yang digelar oleh Disparbudpora Sumenep sebagai media komunikasi dalam membangun citra budaya Sumenep sehingga membuat masyarakat aware dengan budaya lokal. Hasil penelitian tersebut menunjukkan bahwa Disparbudpora Sumenep banyak menampilkan nilai-nilai budaya lokal dalam upaya branding-nya melalui festival.

Berdasarkan penelitian yang sudah peneliti lakukan sebelumnya, ternyata semua objek penelitian tersebut sudah diakomodasi dalam program Visit Sumenep. Ada hal yang menarik untuk dikaji dalam membahas industri pariwisata Sumenep. Sekalipun letak geografisnya kurang menguntungkan karena termasuk daerah tujuan, jumlah kunjungan wisatawan setiap tahunnya ke Sumenep semakin meningkat. Perlu dipelajari, bagaimana manajemen kesan Dinas Pariwisata, Kebudayaan, Pemuda dan Olahraga Sumenep dalam membangun citra destinasi wisatanya sehingga tetap dapat mampu menarik perhatian wisatawan untuk berkunjung ke Sumenep?

Sejumlah penelitian sebelumnya tentang manajemen kesan lebih banyak mengkaji tentang manajemen kesan individu. Contohnya adalah penelitian pengelolaan kesan etnik Bugis dalam proses beradaptasi dengan budaya Sunda (Bahfiarti, 2013) dan pengelolaan kesan mahasiswa pengguna OOTD style di Instagram (Fauzi \& Nuraeni, 2017). Pada kedua penelitian tersebut, manajemen kesan digunakan oleh individu untuk mencapai tujuannya masing-masing. Ini berbeda dari kajian yang dilakukan peneliti yang mengupas manajemen kesan dalam membangun citra destinasi wisata.

Manajemen kesan dalam konteks nonindividu memang jarang dibahas. Akan tetapi, hal tersebut pernah dikaji oleh Tine Silvana Rachmawati dalam penelitiannya 
mengenai program Corporate Social Responsibility. Pada penelitian tersebut, kajian manajemen kesan digunakan untuk melihat bagaimana upaya perusahaan membangun citranya melalui program Corporate Social Responsibility. Dengan kata lain, manajemen kesan tidak digunakan dalam konteks individu, tetapi dalam konteks organisasi.

Sama halnya dengan individu, sebuah organisasi dapat menggunakan teori manajemen impresi ini untuk mempresentasikan dirinya kepada khalayak (Kriyantono, 2014). Dari pernyataan tersebut dapat disimpulkan bahwa manajemen kesan penting untuk membangun impresi publik sesuai dengan apa yang diinginkan.

Penelitian kepariwisataan lebih banyak menggunakan kajian public relations, seperti pada penelitian aktivitas public relations untuk meningkatkan citra taman wisata Candi Borobudur (Raturoma \& Wijaya, 2018) dan peran humas dalam menyebarluaskan pembangunan pariwisata di kabupaten Bantaeng (Tahir, Junaedi \& Rahmat, 2019). Pada kedua penelitian tersebut dilakukan kajian tentang aktivitas public relations dalam membangun pariwisata di daerahnya. Dengan demikian, fokus penelitiannya berbeda dengan penelitian ini yang mengupas manajemen kesan dalam membangun citra destinasi wisata.

Manajemen kesan, atau juga dikenal dengan manajemen impresi, adalah cara yang digunakan untuk mengelola kesan pada publik. Teori manajemen kesan berbicara mengenai upaya untuk menggambarkan diri atau konsep diri pada orang lain atau publik dengan menggunakan komunikasi (Johannson dalam Kriyantono, 2014).
Artinya, dengan menggambarkan dirinya kepada orang lain, maka secara otomatis seseorang akan memiliki impresi atau kesan terhadap apa yang dilihatnya. Agar kesan yang muncul di publik sesuai harapan, maka komunikasi yang dilakukan untuk menggambarkan apa yang ingin dikesankan pada publik harus dikelola dengan tepat.

Kesan merupakan cerminan citra dari suatu organisasi, individu bahkan daerah. Artinya, apabila kesan yang muncul di benak publik baik, maka citranya pun juga baik. Aprinta (2014) menyatakan bahwa citra merupakan kesan, perasaan atau gambaran diri publik terhadap suatu objek atau orang. Selain itu, citra juga merupakan hasil penilaian dari masyarakat terhadap sebuah perusahaan. Apabila publik memiliki kesan yang baik, secara tidak langsung tingkat kepercayaan mereka pun akan meningkat (Windriati, 2019).

Edward Jones, dalam Kriyantono (2014), menyampaikan bahwa ada lima tipologi strategi dalam membangun kesan publik. Kelima strategi tersebut adalah ingratiation (menyenangkan orang lain), yakni strategi penyampaian pesan yang menampilkan citra sebagai pihak yang menyenangkan bagi publik, senang membantu, menghargai pihak lain, dan menunjukkan emosi positif.

Strategi kedua adalah self-promotion (promosi diri), yang dilakukan dengan menampilkan diri sebagai pihak yang kompeten melalui unjuk prestasi, penghargaan, serta hal-hal positif yang sudah dilakukan. Strategi ketiga adalah exemplification (memberi keteladanan), yang dilakukan dengan menampilkan diri sebagai pihak yang dapat dijadikan contoh/model bagi pihak lain. Biasanya, hal ini dilakukan 
dengan cara mendemonstrasikan keahlian dan lain sebagainya.

Strategi keempat adalah supplication, yang menampilkan citra sebagai pihak lemah yang membutuhkan pertolongan atau korban dari suatu krisis. Strategi terakhir adalah intimidation (intimidasi), yang menampilkan citra sebagai pihak yang memiliki power (kekuatan) dan menimbulkan rasa takut pada lawan.

Pada teori manajemen kesan, komunikasi digunakan untuk menghasilkan kesan yang diinginkan. Hal tersebut bersinggungan dengan salah satu fungsi komunikasi instrumental, yang bertujuan untuk menginformasikan, mendorong, mengubah sikap dan perilaku, baik dalam jangka panjang maupun pendek (Mulyana, 2016). Guna mencapai tujuan tersebut, diperlukan pengelolaan kesan, seperti berperilaku sopan di hadapan publik, menggunakan atribut yang sesuai dan lain sebagainya (Moerdijati, 2012).

Dengan demikian, manajemen kesan merupakan upaya mengelola kesan yang dilakukan oleh orang lain atau publik agar sesuai dengan apa yang diinginkan oleh pengirim pesan (komunikator). Komunikator menggunakan beragam cara dalam upayanya untuk mengubah kesan dari orang lain (komunikan), baik melalui pesan ataupun medianya, agar tujuannya tercapai.

\section{METODOLOGI PENELITIAN}

Metode penelitian yang digunakan adalah kualitatif dengan jenis penelitian deskriptif. Dalam penelitian ini, peneliti menggali secara mendalam data mengenai manajemen kesan Dinas Pariwisata, Kebudayaan, Pemuda dan Olahraga Sumenep dalam membangun citra destinasi wisata untuk kemudian dideskripsikan dalam bentuk narasi. Dalam hal ini, peneliti berusaha untuk memaparkan gambaran strategi manajemen kesan yang digunakan berdasarkan teori manajemen kesan. Pengumpulan data dalam penelitian ini menggunakan teknik observasi dan wawancara. Dalam penelitian kualitatif, wawancara digunakan untuk memperoleh kedalaman data, sehingga memungkinkan dilakukan analisis yang mendalam. Pada penelitian ini, data tersebut didapat dari informan kunci, yakni Ronny Arif selaku Kepala Seksi Promosi Dinas Pariwisata, Kebudayaan, Pemuda dan Olahraga Sumenep. Informan ini dipilih karena ialah yang bertanggung jawab dalam mempromosikan kepariwisataan di Sumenep. Informan berikutnya ditetapkan dengan metode insidental, yaitu menentukan informan dengan cara memilih beberapa wisatawan yang kebetulan berkunjung ke Sumenep, seperti Yusta, Riska dan Dina. Informan tersebut dipilih secara acak untuk mendapatkan sudut pandang dari wisatawan yang berkunjung. Adapun observasinya digunakan untuk mengamati kegiatan yang ada pada Program Visit Sumenep. Keabsahan data diverifikasi dengan menggunakan teknik triangulasi sumber, ketika peneliti mengonfirmasi jawaban dari para informan dengan teknik pengambilan data yang sama (Sugiyono, 2018). Analisis data dilakukan dengan menggunakan metode analisis Miles \& Huberman (2007). Dalam metode ini, analisis data dilakukan melalui tahapan reduksi data yang mengumpulkan data hasil wawancara dan observasi dan memilah data yang akan digunakan. Tahap selanjutnya adalah menyajikan data dalam bentuk narasi, seperti kutipan hasil wawancara pada setiap informan. Tahap terakhir adalah verifikasi 
keabsahan data tersebut dengan menggunakan triangulasi untuk mendapatkan data yang valid sehingga dapat digunakan untuk menarik suatu kesimpulan.

\section{HASIL DAN PEMBAHASAN}

Dinas Pariwisata, Kebudayaan, Pemuda dan Olahraga Sumenep dalam upayanya membangun citra destinasi wisata memiliki program utama yang dinamakan program Visit Sumenep. Program ini dibuat dengan tujuan untuk menyampaikan informasi kepada wisatawan bahwa Sumenep memiliki berbagai potensi wisata.

Ada hal menarik yang menjadi temuan peneliti, yaitu mengenai kondisi geografis Sumenep yang masuk dalam kategori daerah tujuan, bukan daerah transit. Wilayah yang termasuk daerah transit membutuhkan upaya yang lebih besar dalam menarik wisatawan untuk berkunjung ke Sumenep. Ini disebabkan kondisi geografis yang membuat wisatawan tidak bisa kemana-mana selain ke Sumenep.

Di sinilah letak hambatan dalam menarik wisata untuk berkunjung ke Sumenep. Akan tetapi, hambatan tersebut berupaya diatasi oleh Dinas Pariwisata, Kebudayaan, Pemuda dan Olahraga Sumenep dengan mengangkat berbagai macam potensi pariwisata yang dimiliki oleh Sumenep.

Program Visit Sumenep ini digunakan sebagai media membangun citra destinasi wisata di Sumenep. Pada program tersebut disampaikan berbagai macam informasi mengenai event yang akan diselenggarakan selama satu tahun di Sumenep. Hal tersebut tertuang dalam kutipan wawancara dengan Kepala Seksi Promosi, sebagai berikut:

"Program Visit Sumenep di dalamnya ada semisal acara festival musik Tong- tong itu setahun sekali kami adakan, musik Tong-tong itu kentongan yang diarak keliling kota Sumenep. Supaya masyarakat tahu, ini loh Sumenep. Terus, ada festival kuliner, itu sepanjang jalan kami suguhkan makanan-makanan khas Sumenep. Ada juga perlombaan Kerapan Sapi, Sapi Sonok, terus ada juga acara kirab keris, dan acara-acara yang dilakukan di lokasi-lokasi wisata, seperti Pantai Sembilan dan Pantai Lombang. Intinya, semua potensi wisata yang ada di Sumenep kami tampilkan dalam Program Visit Sumenep". (Ronny Arif Y, Wawancara, Kepala Seksi Promosi Dinas Pariwisata, Kebudayaan, Pemuda dan Olahraga Sumenep).

Berdasarkan pernyataan informan di atas, ada beberapa kegiatan yang ditonjolkan dalam Program Visit Sumenep, termasuk potensi alam yang dimiliki oleh Sumenep, seperti pantai dan pulau gilinya. Pulau Madura dikenal memiliki banyak pulau kecil, terutama di Sumenep. Yang terbaru, Sumenep memperkenalkan objek wisata Gili Labak, Gili Yang, dan Pantai Sembilan.

Ada juga wisata religi, seperti pemakaman raja-raja Sumenep yang dikenal dengan Asta Tinggi. Banyaknya wisatawan yang berziarah ke makam raja Sumenep ini membuat makam raja Sumenep menjadi semakin dikenal di kalangan wisatawan religi. Wisatawan yang datang berasal dari berbagai daerah, terutama Jawa. Lalu ada Keraton Sumenep yang juga menjadi salah satu objek wisata dalam rangkaian Program Visit Sumenep.

Selain itu, untuk wisata budaya, Dinas Pariwisata, Kebudayaan, Pemuda dan Olahraga Sumenep juga mengangkat 
berbagai budaya Sumenep dalam bentuk festival, pagelaran maupun pameran. Contohnya adalah parade musik Tong-tong (yang merupakan alat musik tradisional Sumenep), musik Saronen (alat musik yang dulunya digunakan sebagai media penyebaran agama Islam di Sumenep) hingga pameran dan kirab keris (pusaka asli Sumenep) yang menarik perhatian wisatawan mancanegara.

Perlombaan balap sapi yang dikenal dengan Kerapan Sapi, memang sudah melegenda dan dikenal banyak wisatawan. Selain itu, ada kontes kecantikan sapi sonok yang mempertontonkan keelokan sapi betina. Ada pula makanan khas yang dijajakan ke dalam festival kuliner khas Sumenep seperti campor, kaldu kokot, rujak, apen, urap-urap dan lain sebagainya.

Apa yang ditampilkan dalam Program Visit Sumenep ini merupakan gambaran dari kekayaan yang dimiliki Pulau Madura. Dari berbagai event yang diselenggarakan dalam Program Visit Sumenep tersebut, Dinas Pariwisata, Kebudayaan, Pemuda dan Olahraga Sumenep tampak sedang berupaya membuat Sumenep menjadi daerah yang mewakili semua daerah di Madura.

Sejak lama, Madura dikenal dengan Kerapan Sapinya. Oleh karena itu, Dinas Pariwisata, Kebudayaan, Pemuda dan Olahraga Sumenep menyelenggarakan perlombaan kerapan sapi sebanyak dua hingga tiga kali setahun, yang dimasukkan dalam Program Visit Sumenep.

Selain itu, Madura juga dikenal sebagai daerah kepulauan dengan pantainya yang eksotis. Kekayaan alam itu berupaya ditampilkan oleh Dinas Pariwisata, Kebudayaan, Pemuda dan Olahraga Sumenep dengan memperkenalkan Gili Labak, Gili
Yang, Pantai Lombang, Pantai Sembilan dan lain sebagainya.

Madura juga dikenal dengan pusaka khasnya, yaitu celurit dan keris. Oleh karena itu, Dinas Pariwisata, Kebudayaan, Pemuda dan Olahraga Sumenep membuat acara pameran keris di keraton dan mempersilakan wisatawan untuk dapat melihat prosesi kirab keris (mensucikan keris). Madura bahkan mendeklarasikan diri sebagai daerah dengan pengrajin keris terbanyak di dunia sekaligus pengrajin keris terbesar.

Selain itu, Madura juga dikenal dengan kulinernya yang melegenda, seperti kaldu kokot. Kekayaan kuliner tersebut juga disajikan oleh Dinas Pariwisata, Kebudayaan, Pemuda dan Olahraga Sumenep dalam festival kuliner di Sumenep. Madura juga dikenal sebagai bekas wilayah kerajaan. Hal itu tak luput ditampilkan oleh Dinas Pariwisata, Kebudayaan, Pemuda dan Olahraga Sumenep dalam bentuk tour ke Museum dan Keraton Sumenep dengan didampingi oleh guide yang telah disiapkan oleh Dinas. Bahkan pada tahun 2018, Sumenep menjadi tuan rumah event Sumenep Mengukir dan puncak acaranya adalah festival keraton dan masyarakat adat seASEAN.

Hal tersebut dipertegas dengan pesan yang disampaikan oleh Dinas Pariwisata, Kebudayaan, Pemuda dan Olahraga Sumenep dengan tagline The Soul of Madura yang selama ini melekat dalam Program Visit Sumenep. Dengan slogan The Soul of Madura, Dinas Pariwisata, Kebudayaan, Pemuda dan Olahraga Sumenep secara tersirat menyatakan bahwa Sumenep memiliki apapun yang orang cari di Madura. Dengan kata lain, jika wisatawan ingin menjelajahi Madura, silakan datang ke 
Sumenep karena semuanya ada. Ditinjau dari teori manajemen kesan, strategi yang paling banyak digunakan oleh Dinas Pariwisata, Kebudayaan, Pemuda dan Olahraga Sumenep dalam membangun citra destinasi wisatanya adalah ingratiation. Sebagaimana dijelaskan sebelumnya, strategi ingratiation dalam membangun kesan yang menjadi tujuan organisasi dilakukan dengan berupaya menjadi pihak yang menyenangkan atau memberikan suatu hiburan bagi publik. Hal ini tampak pada Program Visit Sumenep yang mayoritas event-nya dikemas dalam bentuk festival dan hiburan.

Hal tersebut juga terlihat dalam hasil wawancara berikut:

"Konsep dari Program Visit Sumenep memang banyak dibuat dalam bentuk hiburan, karena prinsipnya jika orang senang dengan apa yang kita berikan, maka orang tersebut akan mudah mengingat apa yang sudah kita berikan. Di situ, secara tidak langsung, orang akan mengenal destinasi wisata apa saja yang ada di Sumenep”. (Ronny Arif Y, Wawancara, Kepala Seksi Promosi Dinas Pariwisata Kebudayaan Pemuda dan Olahraga Sumenep).

Apa yang disampaikan oleh Ronny Arif tersebut, sesuai dengan apa yang disampaikan oleh informan lainnya. Berikut kutipannya:

"Iya, memang beberapa tahun ini sering diadakan acara festival. Positifnya, masyarakat jadi memiliki hiburan dan, yang pasti, senang dengan Sumenep yang meriah seperti sekarang. Selain itu, acara itu juga bisa sekaligus mengenalkan destinasi- destinasi wisata yang ada di Sumenep

ke masyarakat luas". (Dina,

Wawancara, Wisatawan).

Pernyataan kedua informan tersebut menunjukkan bahwa Dinas Pariwisata, Kebudayaan, Pemuda dan Olahraga Sumenep berupaya membangun citra destinasi wisata yang ada di Sumenep dengan mengemasnya dalam bentuk hiburan. Festival dan hiburan yang ditampilkan oleh Dinas Pariwisata, Kebudayaan, Pemuda dan Olahraga Sumenep bukan hanya sekedar memberikan hiburan ala kadarnya, melainkan juga memperhatikan kekayaan budaya yang menjadi karakteristik Sumenep.

Hal ini tampak pada festival musik Tong-tong. Musik tradisional yang biasanya hanya ditampilkan pada event hari jadi Sumenep ini merupakan ansambel musik kentongan yang dipukul dengan irama cepat dan dimainkan di atas kendaraan parade. Musik Tong-tong dipilih untuk masuk ke dalam Program Visit Sumenep karena merupakan budaya khas Sumenep dan mencerminkan karakter masyarakat Madura yang enerjik, ramah terhadap orang lain dan memiliki harga diri yang tinggi (Romadhan, 2020). Diharapkan, wisatawan yang melihat parade musik ini akan terkesan dengan budaya yang dimiliki oleh Sumenep.

Selain musik, Program Visit Sumenep juga menampilkan festival kuliner yang menyuguhkan sajian masakan khas Sumenep seperti campor, kaldu kokot dan lain sebagainya. Dengan diselenggarakannya event ini, wisatawan yang berkunjung akan mengetahui kekayaan kuliner Sumenep, yang tidak kalah lezatnya dengan di tempat lain.

Gelaran lain yang juga selalu ada dalam rangkaian Program Visit Sumenep adalah 
Kerapan Sapi dan kontes kecantikan sapi sonok. Pada Kerapan Sapi, sapi jantan saling berpacu untuk menjadi yang tercepat, sedangkan pada sapi sonok, sapi betina saling bersaing keelokan. Perlombaan sapi ini sesuai dengan Madura yang dikenal sebagai produsen sapi merah. Penyelenggaraan festival tersebut akan membuat wisatawan mengetahui bahwa sapi merah Madura bukan hanya dikonsumsi dagingnya, melainkan juga digunakan dalam kontes kecantikan dan pacuan sapi.

Dalam teori manajemen kesan disebutkan bahwa ketika orang mendapatkan kesenangan dan kenyamanan, akan timbul kesan yang baik terhadap apa yang diterimanya. Biasanya, hal tersebut akan lebih mudah masuk ke dalam persepsi seseorang serta berpeluang untuk bertahan lebih lama dalam ingatan.

Hal itulah yang membuat wisatawan yang pernah berkunjung, kembali lagi berwisata ke Sumenep. Mereka yang baru berkunjung sekali akan kembali datang dengan waktu kunjungan yang lebih lama, terutama ketika ada jadwal acara festival dalam Program Visit Sumenep. Bahkan, ketika kembali berkunjung, mereka juga mengajak rekan-rekan yang lain yang juga penasaran dengan Sumenep.

Dengan demikian, upaya Dinas Pariwisata, Kebudayaan, Pemuda dan Olahraga Sumenep untuk membangun citra destinasi wisata Sumenep, diwujudkan dengan menyelenggarakan program Visit Sumenep yang memberikan hiburan dan kesenangan pada wisatawan. Kesan yang ingin ditimbulkan melalui strategi ingratiation ini adalah bahwa Sumenep memiliki banyak potensi pariwisata, baik dalam hal budaya maupun kulinernya. Selain ingratiation, Dinas Pariwisata, Kebudayaan, Pemuda dan
Olahraga Sumenep juga melakukan strategi lain dalam membangun citra destinasi wisata yang ada di Sumenep. Strategi tersebut adalah self-promotion, yang merupakan strategi kedua dari manajemen kesan, yang dilakukan dengan menampilkan hal-hal positif dan prestasi yang sudah diraih.

Strategi self-promotion tampak dalam penonjolan keunggulan yang dimiliki Sumenep, yang tidak ditemukan di tempat lain. Contohnya adalah dengan dinobatkannya Sumenep sebagai wilayah dengan jumlah pengrajin keris terbanyak di dunia. Prestasi tersebut dipromosikan oleh Dinas Pariwisata, Kebudayaan, Pemuda dan Olahraga Sumenep. Keris merupakan salah satu pusaka asli Sumenep dan hal tersebut dikemas oleh Dinas Pariwisata, Kebudayaan, Pemuda dan Olahraga Sumenep dalam memperkenalkan destinasi wisata budayanya pada wisatawan.

Selain itu, pengrajin keris di Sumenep juga membuat keris terbesar di Indonesia. Prestasi tersebut juga dipromosikan oleh Dinas Pariwisata, Kebudayaan, Pemuda dan Olahraga Sumenep sebagai cara untuk membangun kesan kepada wisatawan mengenai wisata budaya yang ada di Sumenep.

Ada cara unik yang dilakukan oleh Dinas Pariwisata, Kebudayaan, Pemuda dan Olahraga Sumenep dalam mengenalkan keris kepada wisatawan. Caranya adalah dengan memberi kesempatan kepada masyarakat untuk mengikuti prosesi pensucian pusaka keris, yang dikenal sebagai kirab keris. Dalam kegiatan tersebut, wisatawan dapat melihat proses ritual secara lengkap. Upaya ini ternyata mampu menarik perhatian wisatawan, khususnya wisatawan mancanegara.

Selain mempromosikan potensi wisata budaya, Dinas Pariwisata, Kebudayaan, 
Pemuda dan Olahraga Sumenep juga menggaungkan potensi wisata alam di Sumenep. Salah satunya adalah Pantai Lombang. Pantai ini terkenal dengan hamparan pasir putihnya dan menjadi salah satu dari dua tempat tumbuhnya pohon cemara di Indonesia. Selain itu, ada pula Gili Labak, dengan pesona bawah lautnya yang masih alami dan terumbu karangnya yang asri. Kemudian juga ada Gili Yang, yang merupakan pulau dengan kadar oksigen kedua tertinggi di dunia, yang menjadi andalan Sumenep dalam menarik perhatian wisatawan. Hal tersebut tampak dalam wawancara dengan Dinas Pariwisata, Kebudayaan, Pemuda dan Olahraga Sumenep berikut:

"Jelas itu, jadi kita tunjukkan apa yang sudah kita dapat. Keris misalnya, Sumenep kan dinobatkan sebagai pengrajin keris terbanyak di dunia, nah itu kita buat acara pembersihan keris agar bisa dilihat orang banyak. Selain itu, salah satu pulau di Sumenep, Pulau Gili yang dinobatkan sebagai pulau dengan kadar oksigen yang tinggi, nah itu juga kita kenalkan ke masyarakat". (Ronny Arif Y, Wawancara, Kepala Seksi Promosi Dinas Pariwisata, Kebudayaan, Pemuda dan Olahraga Sumenep).

Penjelasan di atas menunjukkan bahwa Dinas Pariwisata, Kebudayaan, Pemuda dan Olahraga Sumenep berusaha mempromosikan potensi pariwisata Sumenep melalui Program Visit Sumenep. Di dalam program itu ditonjolkan potensi pariwisata yang dimiliki oleh Sumenep, seperti Kerapan Sapi dan Sapi Sonok. Demikian pula dengan keindahan alam Sumenep seperti festival yang dilakukan di Pantai Lombang, Pantai Sembilan dan lain sebagainya. Dalam hal ini, Dinas Pariwisata, Kebudayaan, Pemuda dan Olahraga Sumenep belum mengoptimalkan pemanfaatan media digital, seperti media online dan media sosial, untuk mempromosikan pariwisatanya. Yang dilakukan adalah mengonsep satu kesatuan acara yang menarik perhatian wisatawan sehingga mendorong publikasi dari wisatawan yang datang. Artinya, Dinas memanfaatkan warga net atau netizen untuk mempublikasikan destinasi wisata Sumenep ke akun media sosial mereka masing-masing.

Selain itu, dengan menunjukkan potensi terbaik yang dimiliki Sumenep, wisatawan akan mudah memperhatikan. Ini karena orang akan cenderung lebih fokus jika ada kata-kata terbanyak, tertinggi, dan istilah-istilah sejenis. Penggunaan istilah superlatif cenderung akan membuat orang penasaran, sehingga cara yang dilakukan oleh Dinas Pariwisata Kebudayaan Pemuda dan Olahraga Sumenep tersebut efektif dalam memperkenalkan objek wisata di Sumenep kepada wisatawan.

Strategi self-promotion ini juga yang ternyata membuat wisatawan mulai memperhatikan destinasi wisata yang ada di Sumenep. Salah satu wisatawan menyampaikan bahwa ia tertarik untuk datang ke Sumenep karena melihat unggahan mengenai keindahan Pulau Gili Labak dan Pantai Lombangnya. Berikut contoh unggahan yang diambil dari akun Instagram @wisatasumenep:

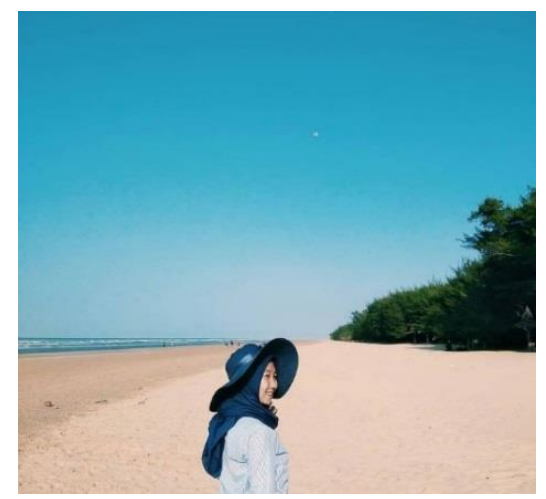

Gambar 3. Pantai Lombang Sumenep 
Selain itu, seperti disampaikan oleh informan pada kutipan berikut:

"Kami tahunya Sumenep dari media sosial. Kebetulan waktu itu saya melihat unggahan teman bahwa di Sumenep sedang ramai wisatanya. Salah satunya adalah pulau yang banyak oksigennya. Saya juga lihat pantai Lombang yang dikenal dengan pasir putihnya yang bersih dan ternyata itu benar". (Riska, Wawancara, Wisatawan Domestik).

Upaya Dinas Pariwisata, Kebudayaan, Pemuda dan Olahraga Sumenep melalui strategi self-promotion yang menampilkan berbagai macam potensi alam Sumenep seperti ingin membangun kesan bahwa Sumenep memiliki pesona destinasi wisata alam yang tidak kalah dengan di tempat lain.

Strategi ketiga dari manajemen kesan adalah exemplification (memberi contoh). Secara langsung, Dinas Pariwisata, Kebudayaan, Pemuda dan Olahraga Sumenep belum menggunakan strategi ini. Menurut pandangan mereka, Sumenep masih mencoba membangun pariwisata daerahnya dengan melakukan studi banding ke daerah lain yang sudah lebih maju pengelolaan destinasi wisatanya. Hal tersebut tampak dalam penuturan informan berikut:

"Kalau itu belum sepertinya, kita sendiri masih mencoba membangun role model dalam mengelola pariwisata di Sumenep. Oleh karena itu, kita sering melakukan studi banding ke kota lain yang wisatanya sudah maju, seperti Malang, Banyuwangi dan Bali. Nah, dari situ kita mencoba untuk menerapkan apa yang kira-kira bisa diterapkan dalam membangun destinasi wisata di
Sumenep”. (Ronny Arif Y, Wawancara, Kepala Seksi Promosi Dinas Pariwisata, Kebudayaan, Pemuda dan Olahraga Sumenep).

Dari pernyataan di atas diketahui bahwa Sumenep belum menjadi percontohan bagi daerah lain dalam mengelola pariwisatanya. Namun, jika melihat kondisi objek wisata di Sumenep dan upaya Dinas Pariwisata, Kebudayaan, Pemuda dan Olahraga Sumenep untuk mempromosikannya melalui Program Visit Sumenep, Sumenep dapat dikatakan sudah mampu menjadi percontohan bagi daerah lain dalam mengelola destinasi wisatanya.

Di mata wisatawan, Sumenep terkenal dengan objek wisata budaya dan alam, seperti pantai dan pulau-pulaunya. Hal tersebut sesuai dengan apa yang dikesankan oleh Dinas Pariwisata, Kebudayaan, Pemuda dan Olahraga Sumenep. Cara yang dilakukan oleh Dinas Pariwisata, Kebudayaan, Pemuda dan Olahraga Sumenep juga layak dijadikan percontohan bagi daerah lain. Misalnya saja dalam menonjolkan destinasi wisata Sumenep, Dinas telah memilih yang memang sesuai dan menjadi karakteristik Sumenep. Sumenep memiliki objek wisata pantai, pulau dan budaya, sehingga hal itulah yang dipromosikan untuk menarik perhatian wisatawan. Dengan demikian, terdapat kesesuaian antara potensi yang dimiliki dan kesan yang ingin dibangun dan sinkronisasi ini memudahkan wisatawan untuk mengingatnya.

Dengan suksesnya Program Visit Sumenep dua tahun terakhir yang mampu meningkatkan jumlah wisatawan secara signifikan, sangatlah layak jika Dinas Pariwisata, Kebudayaan, Pemuda dan Olahraga Sumenep menjadi percontohan bagi daerah lain dalam membangun pariwisatanya. 
Strategi keempat adalah supplication, yang menggunakan kelemahan sebagai alat untuk menarik perhatian. Strategi ini tidak digunakan oleh Dinas Pariwisata, Kebudayaan, Pemuda dan Olahraga Sumenep. Justru kelemahan yang dimiliki Sumenep berupaya ditutupi dengan keunggulan yang lain. Hal tersebut tampak dalam kutipan wawancara berikut:

"Walaupun memang Sumenep dalam hal jarak ini lumayan jauh, hanya memiliki bandara yang kecil dan terbatas, dan juga bukan daerah transit, tapi kami yakin destinasi wisata di Sumenep ini bisa dikenal di masyarakat luas, karena itu dibuat Program Visit Sumenep”. (Ronny Arif Y, Wawancara, Kepala Seksi Promosi Dinas Pariwisata, Kebudayaan, Pemuda dan Olahraga Sumenep).

Pernyataan informan di atas menunjukkan bahwa Dinas Pariwisata, Kebudayaan, Pemuda dan Olahraga Sumenep tidak menggunakan kelemahannya sebagai bukan daerah transit untuk menarik perhatian publik. Dinas justru berusaha mengatasi kelemahan tersebut dengan menunjukkan potensi destinasi wisata Sumenep melalui Program Visit Sumenep. Dinas Pariwisata, Kebudayaan, Pemuda dan Olahraga Sumenep tidak menunjukkan bahwa Sumenep merupakan lokasi wisata yang jauh untuk dikunjungi ataupun bukan daerah transit. Dinas justru berupaya untuk lebih menonjolkan potensi alam dan budaya yang dimiliki Sumenep sehingga wisatawan mau berkunjung.

Hal tersebut juga berlaku pada strategi terakhir dalam teori manajemen kesan, yaitu intimidation (intimidasi). Strategi yang menonjolkan kekuatan atau power yang dimiliki untuk menarik perhatian ini juga tidak digunakan oleh Dinas Pariwisata, Kebudayaan, Pemuda dan Olahraga Sumenep. Hal ini karena industri pariwisata di Sumenep masih tergolong baru dan berkembang. Dengan kata lain, strategi yang digunakan lebih banyak menonjolkan keunggulan destinasi wisata yang dimiliki dan menjadi tuan rumah yang menyenangkan bagi wisatawan yang berkunjung ke Sumenep.

\section{KESIMPULAN DAN SARAN}

Dalam membangun citra destinasi wisata di Sumenep, Dinas Pariwisata, Kebudayaan, Pemuda dan Olahraga Sumenep menggunakan strategi manajemen kesan ingratiation, self-promotion dan exemplification. Dua strategi lainnya, yakni supplication dan intimidation tidak digunakan. Hal tersebut tampak dari beragam kegiatan untuk mengenalkan destinasi wisata yang ada di Sumenep, khususnya dalam Program Visit Sumenep. Program ini didominasi oleh event pagelaran dan festival serta promosi destinasi wisata, mulai dari wisata alam hingga budaya.

Saran yang dapat diberikan kepada Dinas Pariwisata, Kebudayaan, Pemuda dan Olahraga Sumenep untuk dapat mempertahankan momentum meningkatnya perhatian publik pada sektor pariwisata di Sumenep adalah dengan mempertahankan kegiatan promosi destinasi wisata yang menjadi ikon Sumenep dan digemari oleh wisatawan. Selain itu, perlu dilakukan evaluasi mengenai kegiatan yang kurang digemari oleh wisatawan sehingga ke depannya pemerintah daerah dapat merancang kegiatan yang sesuai dengan keinginan wisatawan. 


\section{UCAPAN TERIMA KASIH}

Peneliti mengucapkan banyak terima kasih kepada kepada Universitas 17 Agustus 1945 Surabaya yang memberikan kepercayaan kepada peneliti untuk memberikan dana Hibah Perguruan tinggi. Peneliti juga menyampaikan rasa terima kasih kepada LPPM Universitas 17 Agustus 1945 Surabaya yang sudah memfasilitasi peneliti untuk dapat menyelesaikan pelaporan dalam penelitian yang peneliti lakukan. Tidak lupa, peneliti menyampaikan terima kasih yang sebesar-besarnya kepada Dinas Pariwisata, Kebudayaan, Pemuda dan Olahraga Sumenep yang sudah membantu peneliti mendapatkan data lapangan selama proses penelitian.

\section{DAFTAR PUSTAKA}

Aprinta E.B, G. (2014). "Strategi Cyber Public Relations dalam Pembentukan Citra Institusi Pendidikan Tinggi Swasta". Jurnal The Messenger, Vol (04), No (1), hal: 1-7.

Archipelago. (2019). Label: Kalender Pariwisata Sumenep 2018. Diakses pada tanggal 28 Juli 2019 dari https://archipelago-

indonesia.com/tag/kalender-pariwisatasumenep-2018/

Bahfiarti, T. (2013). "Pengelolaan Kesan Etnik Bugis Dalam Adaptasi Diri Dengan Budaya Sunda”. Jurnal Komunikasi Kareba, Vol 2(1), 55-64

Fauzi, M. A., \& Nuraeni, R. (2017). "Pengelolaan Kesan Mahasiswa Pengguna Ootd Styledi Instagram (Studi Dramaturgi pada Mahasiswa Pengguna Foto OOTD di akun @ ootdupi)". Jurnal Liski, 3(2), 206-222.
Kriyantono, R. 2014. Teori Public Relations Perspektif Barat dan Lokal. Jakarta: Kencana.

Miles, M. B dan A. H. (2007). Analisis Data Kualitatif Buku Sumber tentang Metode-Metode Baru. (Terj.) Tjetjep Rohendi Rohisi, Jakarta: Universitas Indonesia.

Moerdijati, S. (2012). Pengantar Ilmu Komunikasi. Surabaya: Revka Petra Media

Mulyana, D. (2016). Ilmu Komunikasi, Suatu Pengantar. Bandung: Remaja Rosdakarya.

Rachmawati. T. S., (2019). "Program Corporate Social Responsibility Sebagai Strategi Manajemen Kesan Perusahaan". Jurnal MetaKom Vol (3) No (1), hal: 95-108.

Raturomą Julita M.A. \& Wijaya, Lina Sinatra (2018). “Aktivitas Public Relations dalam Upaya Meningkatkan Citra Taman Wisata Candi Borobudur". Jurnal UltimaComm, 10(2), 114-125.

Romadhan, M. I., Puspaningtyas, A., Rahmadanik, D. (2019). "Proses Komunikasi Dalam Pelestarian Budaya Saronen Kepada Generasi Muda". Jurnal Pikom: Penelitian Komunikasi dan Pembangunan. Vol. 20(01), hal: 112.

Romadhan, M. I., (2019). "Festival Sebagai Media Komunikasi Dalam Membangun Citra Destinasi Wisata Budaya di Sumenep". Jurnal Destinesia Hospitaliti \& Pariwisata.. Vol. 01(01), hal: 1-10.

Romadhan, M. I., (2020) "Membangun Citra Budaya Masyarakat Sumenep Melalui Festival Musik Tong-tong”. MetaCommunication; Journal of 
Communication Studies. Vol. 05(01), hal: 77-92.

Sugiyono. (2018). Metode Penelitian Kuantitatif, Kualitatif, dan R\&D. Bandung: Alfabeta.

Supanjie. (2019). Inilah Rangkaian Kalender Visit Sumenep 2019, Beserta Lokasi Acaranya. Diakses pada tanggal 19 Juli 2019 dari https://faktualnews.co/2019/04/08/inilah -rangkaian-kalender-visit-sumenep2019-beserta-lokasi-acaranya/133450/
Tahir. M. Junaedi. \& Rahmat. J. (2019). "Peran Humas Dalam Menyebarluaskan Pembangunan Pariwisata Di Kabupaten Bantaeng". Jurnal Komunikasi dan Organisasi (JKO) Vol. 1(1). Hal: 39-45.

Windriati, A. R., Darmawan, A. \& Romadhan, M.I., (2019). "Peran Public Relations dalam Membangun Citra di Atlantis Land Surabaya". Jurnal Representamen.. Vol. 51(01), hal: 1-9. 
